УДК 631.95, DOI 10.31210/visnyk2018.02.06

(C) 2018

Тогачинська О. В., кандидат сільськогосподарських наук

Національний університет харчових технологій

Паращенко І. В., кандидат сільськогосподарських наук

Інститут агроекології і природокористування НААН

\title{
ЕКОЛОГІЧНА ЕКСПЕРТИЗА ТЕХНОЛОГІЙ ВИРОЩУВАННЯ ПШЕНИЦІ ОЗИМОЇ В УМОВАХ ПІВНІЧНОГО ЛІСОСТЕПУ
}

\section{Рецензент - доктор сільськогосподарських наук Н. В. Палапа}

Висвітлено результати екологічної експертизи технологій вирощування пшениці озимої у північному Лісостепу за впливом на процеси міграції міді в генетичних горизонтах темно-сірого опідзоленого трунту та накопичення ії у вететативних і генеративних органах рослин. Результати екотоксикологічних досліджень дали змогу виявити, щзо мінеральна система удобрення та інтенсивний захист рослин можуть бути причиною нагромадження потениійно небезпечних икідливих речовин у верхніх горизонтах трунту, а також сприяти їх міграції вниз за грунтовим профілем і створювати потенційну загрозу забруднення грунтових вод.

Ключові слова: пшениия озима, трунт, санітарно-гігієнічні показники, темно-сірий опідзолений трунт, мідь.

Постановка проблеми. До факторів забруднення навколишнього середовища, крім промислових викидів, пестицидів, належить і застосування мінеральних й органічних добрив та вапнякових матеріалів. 3 одного боку, до складу добрив входять важкі метали (BM), які потенційно здатні забруднювати грунт, рослини та грунтові води, з іншого - добрива, змінюючи агрохімічні властивості, можуть впливати на міграцію важких металів у ньому та на їх надходження у рослини [5].

У зв'язку з цим проведення екологічної експертизи технологій вирощування озимої пшениці за санітарно-гігієнічними показниками, а також вивчення міграції міді в генетичних горизонтах темно-сірого опідзоленого грунту і накопичення в генеративних органах пшениці озимої є актуальним питанням.

Аналіз останніх досліджень і публікацій, у яких започатковано розв'язання проблеми. Основними принципами екологічної експертизи технологій вирощування сільськогосподарських культур є гарантування безпечного для життя та здоров'я людей навколишнього природного середовища, збалансованість екологічних, економічних, медико-біологічних і соціальних інтере- сів, наукова обгрунтованість, превентивність [1, $2,5]$. Питаннями вивчення екологічної оцінки технологій вирощування сільськогосподарських культур за комплексом показників займалися провідні вчені в галузі екології: Н. А. Макаренко, Т. Л Жегарьова, Р. М. Алєксахін та інші.

Метою нашої роботи було проведення екологічної експертизи технологій вирощування озимої пшениці за міграції міді в генетичних горизонтах темно-сірого опідзоленого грунту та накопичення міді в генеративних органах озимої пшениці.

Методика проведення дослідження. Дослідження проводились на базі Інституту агроекології УААН та ННЦ „Інститут землеробства УААН". Польові дослідження було проведено в стаціонарному досліді ННЦ „Інститут землеробства”. Сорт пшениці озимої - Лада Одеська. Грунт дослідного поля - темно-сірий опідзолений легкосуглинковий на лесовидному суглинку з наступною характеристикою основних агрохімічних показників: $\mathrm{pH}$ сол $-5,2$, гідролітична кислотність - 39 мг-екв кг грунту, вміст гумусу - 2,0 \% (за Тюріним), рухомого фосфору - 160 мг/кг грунту (за Чириковим), обмінного калію - 140 мг/кг грунту (за Масловою).

У досліді вивчали 2 системи захисту рослин: інтенсивну - 3 використанням пестицидів «Амістар», «Карате-Зеон», «Альто-Супер», «Лінтур»; мінімальну - 3 використанням протруювача насіння «Максім-Стар».

Схема досліду передбачала вивчення варіантів удобрення на фоні мінімальної й інтенсивної системи захисту рослин: контроль (без добрив), $\mathrm{N}_{60} \mathrm{~N}_{30}, \quad \mathrm{P}_{135} \mathrm{~K}_{135}+\mathrm{N}_{80}+\mathrm{N}_{55}$, побічна продукція, $\mathrm{P}_{90} \mathrm{~K}_{90}+\mathrm{N}_{60}+\mathrm{N}_{30}$.

Вміст важких металів визначали в грунті та рослинних зразках. Грунт відбирали 3 орного шару 0-20 см одночасно з рослинними зразками. Рухомі форми важких металів із грунту вилучали за допомогою екстракції 1 н $\mathrm{HNO}_{3}$, а їх кількісне визначення проводили на атомно-адсорбційному спектрофотометрі [3]. 
Статистичну обробку результатів проводили за допомогою дисперсійного і регресійного аналізів.

Результати дослідження. Екологічну експертизу технологій вирощування озимої пшениці проводили відповідно до методичних рекомендацій "Екологічна експертиза технологій вирощування сільськогосподарських культур" [4]. Технології оцінювали за впливом на стан агроекосистеми:

\begin{tabular}{|c|c|c|}
\hline $\begin{array}{c}\text { Екологічний } \\
\text { стан }\end{array}$ & $\begin{array}{c}\text { Відхилення від опти- } \\
\text { муму в бік погіршення }\end{array}$ & Бал \\
\hline $\begin{array}{c}\text { незадовіль- } \\
\text { ний }\end{array}$ & перевищує 25\% & 0 \\
\hline задовільний & $\begin{array}{c}\text { понад } 10 \% \text {, але не } \\
\text { перевищує 25\% }\end{array}$ & 1 \\
\hline нормальний & не перевищує $10 \%$ & 2 \\
\hline оптимальний & не спостерігається & 3 \\
\hline
\end{tabular}

Було проведено екологічну експертизу технологій вирощування озимої пшениці за впливом на процеси міграції важких металів у генетичних горизонтах грунту.

Розподіл важких металів за генетичними горизонтами залежить від процесу грунтоутворення, мінералогічного складу материнських порід, гранулометричного складу і вмісту органічної речовини в грунті $[2,3]$.

Екологічну експертизу проводили за коефіцієнтом концентрації у різних генетичних горизо- нтах грунту, який характеризує ступінь накопичення елементів (важких металів) у грунті відносно контролю:

$\mathrm{Kc}=\mathrm{k}_{\mathrm{i}} / \mathrm{Ki}$,

де $\mathrm{k}_{\mathrm{i}}$ - вміст, $\mathrm{i}$ - хімічного елементу у $\mathrm{n}-$ компоненті, $\mathrm{Ki}$ - вміст і - хімічного елементу в еталоні (контролі).

Величина коефіцієнту концентрації свідчить про активність процесів вилуговування $(\mathrm{Kc}<1) \mathrm{i}$ накопичення $(\mathrm{Kc}>1)$ катіонів у генетичних горизонтах грунту. За величиною коефіцієнту концентрації існує наступна градація (табл. 1).

Нами було проведено екологічне оцінювання темно-сірого опідзоленого грунту за коефіцієнтом концентрації при застосуванні різних технологічних операцій щодо (табл. 2).

Екологічне оцінювання темно-сірого опідзоленого грунту за коефіцієнтом концентрації міді показало, що $\mathrm{N}_{60} \mathrm{~N}_{30}, \mathrm{P}_{135} \mathrm{~K}_{135}+\mathrm{N}_{80}+\mathrm{N}_{55}$ на фоні інтенсивного захисту і $\mathrm{P}_{135} \mathrm{~K}_{135}+\mathrm{N}_{80}+\mathrm{N}_{55}$ на фоні мінімального захисту відповідали нормальному та оптимальному екологічному стану (коефіцієнти концентрації коливалися в межах 1,1-1,5). Це свідчить про незначне накопичення міді у генетичних горизонтах темно-сірого опідзоленого грунту (табл. 2).

Дослідження впливу мінеральних і органічних добрив за мінімального й інтенсивного захисту рослин показали, що внесення добрив протягом тривалого часу не призводило до значного зростанням міді у грунті (рис. 1-2).

1. Оцінка технологї̈ за коефіцієнтами концентрації [1]

\begin{tabular}{|c|c|c|}
\hline Екологічний стан & перевищення коефіцієнту концентрації & Оцінка, бали \\
\hline незадовільний & $\geq 5,0$ & 0 \\
\hline задовільний & $3,0-5,0$ & 1 \\
\hline нормальний & $1,0-2,9$ & 2 \\
\hline оптимальний & $\leq 1,0$ & 3 \\
\hline
\end{tabular}

2. Коефіцієнти концентрації міді при застосуванні різних технологій вироцування пшениці

\begin{tabular}{|c|c|c|c|c|c|c|c|}
\hline \multirow{3}{*}{$\begin{array}{l}\text { Варіанти } \\
\text { досліду }\end{array}$} & \multicolumn{5}{|c|}{ Генетичний горизонт } & \multirow{2}{*}{$\begin{array}{c}\text { Екологічний } \\
\text { стан }\end{array}$} & \multirow{3}{*}{$\begin{array}{l}\text { Оцінка, } \\
\text { бали }\end{array}$} \\
\hline & $\mathrm{He}$ & $\mathrm{Hi}$ & IHgi & Pigl & Pkgl & & \\
\hline & \multicolumn{6}{|c|}{ коефіцієнт концентрації міді } & \\
\hline $\mathrm{N}_{60} \mathrm{~N}_{30}$ & $* 1,1 / * * 1,1$ & $1,2 / 0,9$ & $1,2 / 1,0$ & $1,3 / 1,0$ & $1,2 / 1,0$ & $\begin{array}{l}\text { нормальний/ } \\
\text { оптимальний }\end{array}$ & $2 / 3$ \\
\hline $\begin{array}{c}\mathrm{P}_{135} \mathrm{~K}_{135}+\mathrm{N}_{80}+ \\
\mathrm{N}_{55}\end{array}$ & $1,2 / 1,1$ & $1,4 / 1,0$ & $1,3 / 1,1$ & $1,2 / 1,1$ & $1,2 / 1,0$ & $\begin{array}{c}\text { нормальний/ } \\
\text { нормальний }\end{array}$ & $2 / 3$ \\
\hline $\begin{array}{l}\mathrm{P}_{90} \mathrm{~K}_{90}+ \\
\mathrm{N}_{60}+\mathrm{N}_{30}\end{array}$ & $1,1 / 1,1$ & $1,1 / 1,0$ & $1,0 / 1,0$ & $1,0 / 1,0$ & $1,0 / 1,0$ & $\begin{array}{l}\text { оптимальний/ } \\
\text { оптимальний }\end{array}$ & $3 / 3$ \\
\hline $\begin{array}{c}\text { побічна } \\
\text { продукція }\end{array}$ & $1,1 / 0,9$ & $1,0 / 1,0$ & $0,9 / 0,9$ & $1,0 / 1,0$ & $0,9 / 0,9$ & $\begin{array}{l}\text { оптимальний/ } \\
\text { оптимальний }\end{array}$ & $2 / 3$ \\
\hline
\end{tabular}

*- інтенсивний захист, ** - мінімальний захист 


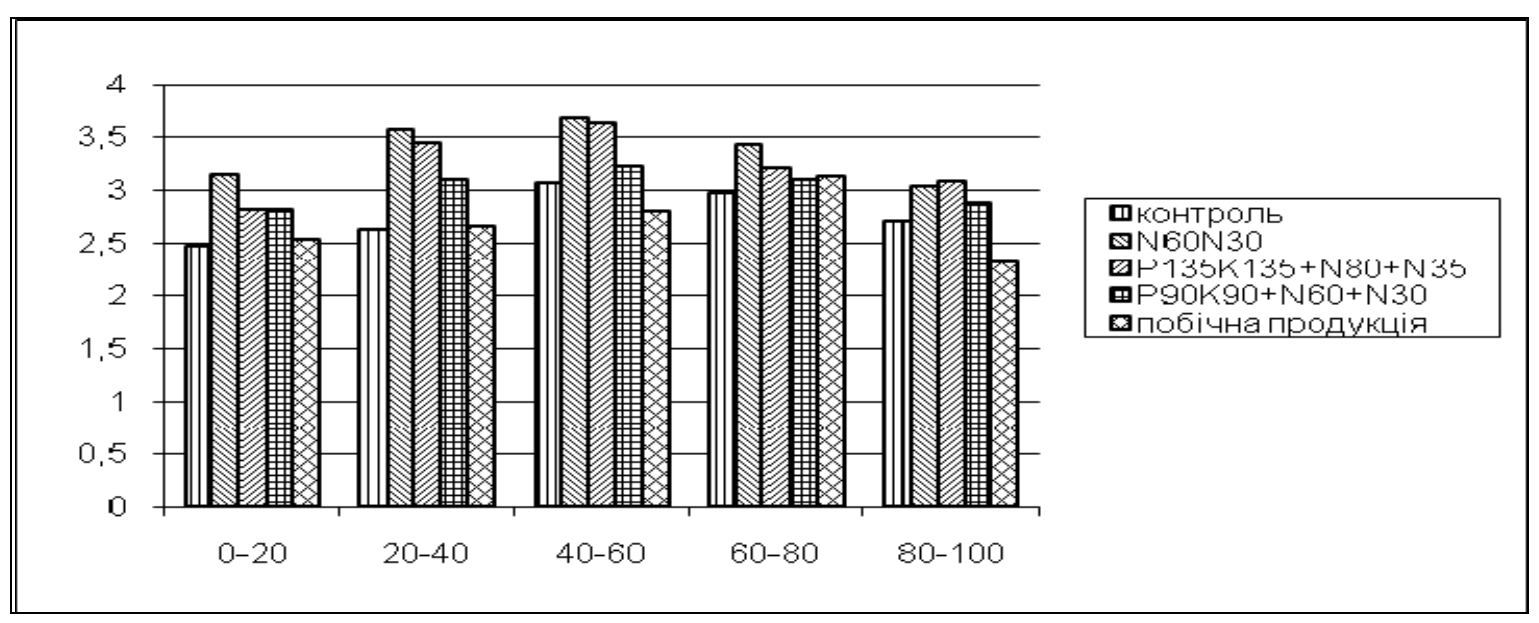

Рис. 1. Розподіл міді за профілем темно-сірого опідзоленого трунту за інтенсивного захисту

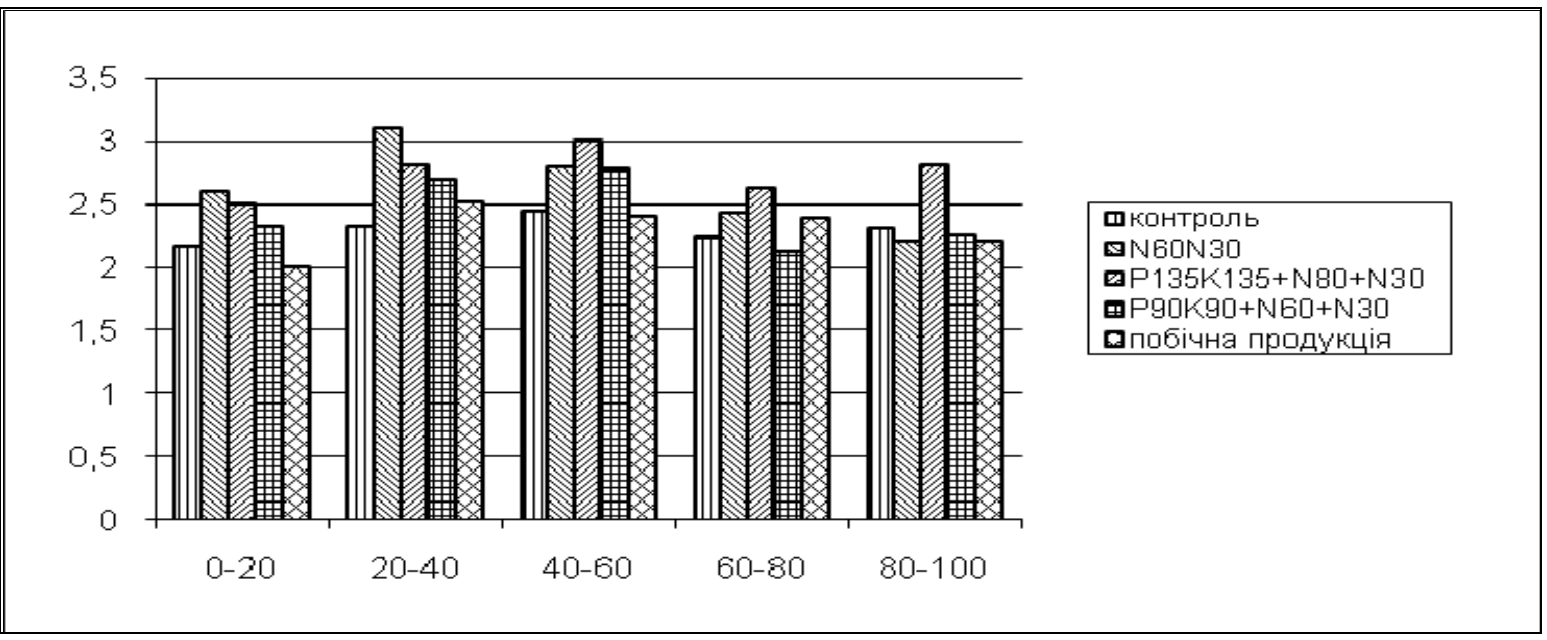

Рис. 2. Розподіл міді за профілем темно-сірого опідзоленого трунту за мінімального захисту

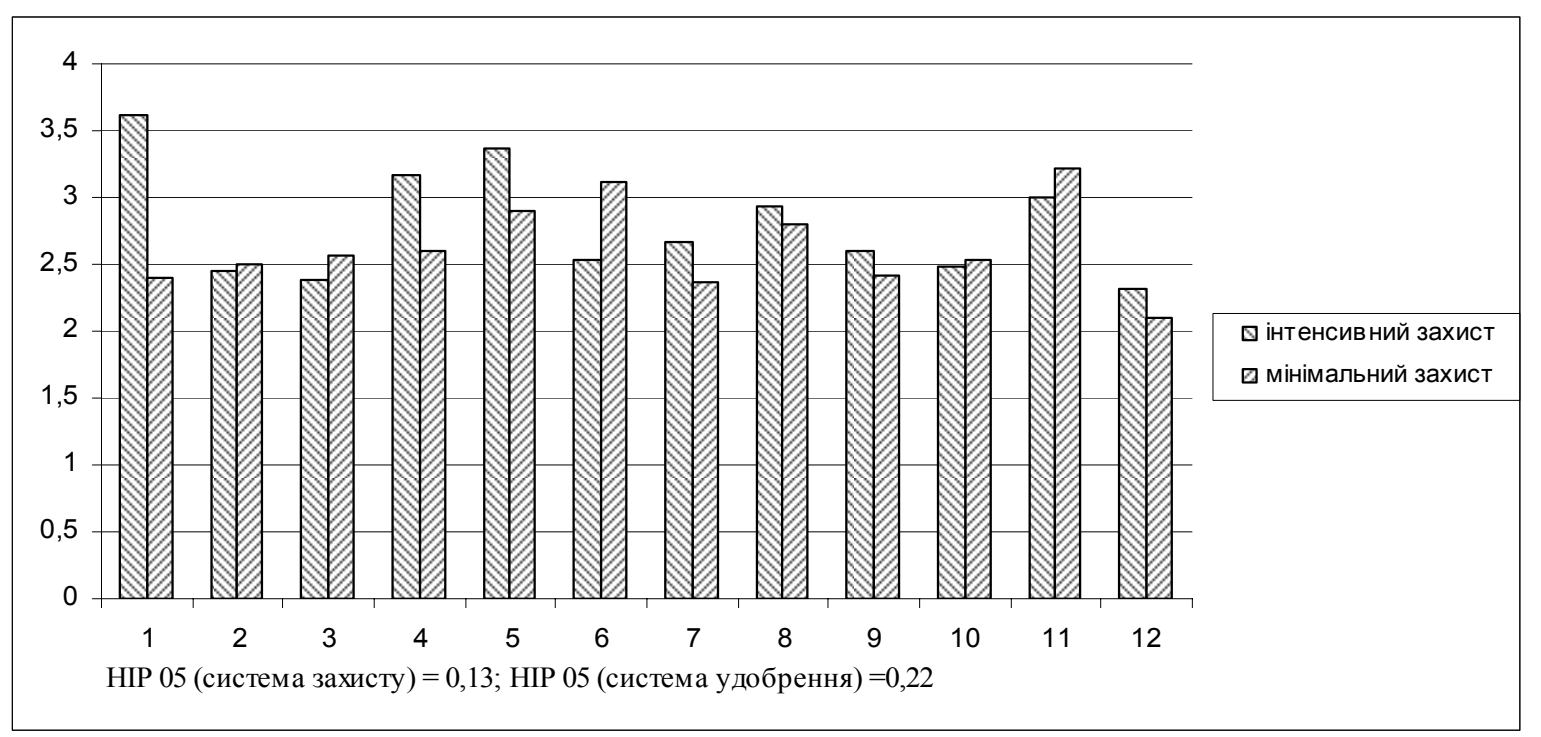

Рис. 3. Вплив технологій вирощування на вміст міді у зерні пиениці озимої $(y$ - вміст міді, мг/кг; $\boldsymbol{x}$ - варіанти досліду) 
СІЛЬСЬКЕ ГОСПОДАРСТВО. РОСЛИННИЦТВО

\section{3. Коефіцієнт біологічного поглинання (К б.л) міді вететативними (солома) і генеративними (зерно) органами пшениці озимої (чисельник - інтенсивна система захисту, знаменник-мінімальна система захисту рослин)}

\begin{tabular}{|l|c|c|c|}
\hline \multirow{2}{*}{\multicolumn{1}{|c|}{ Варіанти }} & \multirow{2}{*}{$\begin{array}{c}\text { Вміст міді у темно-сірому } \\
\text { опідзоленому грунті }\end{array}$} & $\begin{array}{c}\text { Оегетативні } \\
\text { (солома) }\end{array}$ & $\begin{array}{c}\text { генеративні } \\
\text { (зерно) }\end{array}$ \\
\cline { 3 - 4 } & & $1,86 / 1,74$ & $0,90 / 1.07$ \\
\hline $1 . \mathrm{N}_{60} \mathrm{~N}_{30}$ & $2,65 / 2,39$ & $1,80 / 1,63$ & $1,10 / 1,18$ \\
\hline $2 . \mathrm{P}_{135} \mathrm{~K}_{135}+\mathrm{N}_{80}+\mathrm{N}_{55}$ & $3,06 / 2,44$ & $1,90 / 1,89$ & $0,96 / 1,30$ \\
\hline $3 . \mathrm{P}_{90} \mathrm{~K}_{90}+\mathrm{N}_{60}+\mathrm{N}_{30}$ & $2,63 / 2,32$ & $1,48 / 1,79$ & $0,91 / 1,00$ \\
\hline 4. побічна продукція & $2,71 / 2,31$ & $1,60 / 1,52$ & $0,92 / 0,97$ \\
\hline 5. контроль & $2,50 / 2,16$ & \\
\hline
\end{tabular}

4. Екологічне оцінювання технологій вирощування пшениці

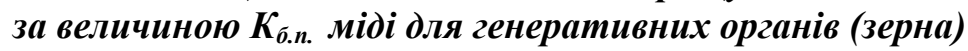

\begin{tabular}{|l|c|c|}
\hline \multirow{2}{*}{\multicolumn{1}{|c|}{ Варіанти }} & \multicolumn{2}{|c|}{ Екологічне оцінювання } \\
\cline { 2 - 3 } & Екологічний стан & Оцінка, бали \\
\cline { 2 - 3 } & оптимальний/задовільний & $3 / 1$ \\
\hline $1 . \mathrm{N}_{60} \mathrm{~N}_{30}$ & задовільний/задовільний & $1 / 1$ \\
\hline $2 . \mathrm{P}_{135} \mathrm{~K}_{135}+\mathrm{N}_{80}+\mathrm{N}_{55}$ & нормальний/задовільний & $2 / 1$ \\
\hline $3 . \mathrm{P}_{90} \mathrm{~K}_{90}+\mathrm{N}_{60}+\mathrm{N}_{30}$ & оптимальний/нормальний & $3 / 2$ \\
\hline 4. побічна продукція & оптимальний/оптимальний & $3 / 3$ \\
\hline 5. контроль &
\end{tabular}

При вирощуванні озимої пшениці вміст важких металів в шарах грунту був нерівномірним. У нижніх шарах грунту кількість їх зменшувалась, порівняно 3 верхніми шарами. При застосуванні $\mathrm{P}_{135} \mathrm{~K}_{135}+\mathrm{N}_{80}+\mathrm{N}_{55}, \mathrm{~N}_{60} \mathrm{~N}_{30}$ відбулося збільшення міді в шарах 20-40, 40-60 см на фоні інтенсивного захисту. На інших варіантах на фоні інтенсивного і мінімально захисту по всьому профілю грунту значного збільшення не помітно.

Було встановлено, що максимальне накопичення міді в зерні відбувалося за інтенсивного захисту у варіантах із внесенням мінеральних добрив $\quad\left(\mathrm{P}_{135} \mathrm{~K}_{135}+\mathrm{N}_{80}+\mathrm{N}_{55}, \quad \mathrm{P}_{90} \mathrm{~K}_{90} \mathrm{~N}_{60}+\mathrm{N}_{30}\right.$, $\mathrm{N}_{45} \mathrm{P}_{45} \mathrm{~K}_{45}$ ), ії вміст становив $3,62,3,87,3,00$ мг/кг відповідно. Так, на інших варіантах вміст міді знизився, порівняно 3 контролем, і складав у зерні пшениці $<2,39$ мг/кг. За мінімального захисту рослин вміст міді у зерні не перевищував 3,12 мг/кг (рис. 3).

Найбільші коефіцієнти біологічного поглинання міді генеративними органами спостерігалися за інтенсивного захисту рослин (табл. 3), вони становили $1,67-1,90$. Коефіцієнти біологічного поглинання міді генеративними органами коливалися в межах 0,82-1,13.

Відповідно до визначених коефіцієнтів біологічного поглинання свинцю було проведено оцінювання технологій вирощування пшениці ози- мої (табл. 4).

Аналогічним чином проводили оцінювання технологій вирощування пшениці за впливом на процеси нагромадження рослинами міді.

Дослідженнями було показано (рис. 3), що на фоні інтенсивного захисту вміст міді в соломі мав також тенденцію до збільшення. Найбільший вміст міді в соломі озимої пшениці відмічено на варіантах $\mathrm{P}_{135} \mathrm{~K}_{135}+\mathrm{N}_{80}+\mathrm{N}_{55}, \mathrm{P}_{90} \mathrm{~K}_{90} \mathrm{~N}_{60}+\mathrm{N}_{30}$, що становив 4,75 мг/кг, 5,52 мг/кг відповідно до контролю. Проте вміст ії за внесення норм добрив $\mathrm{N}_{45} \mathrm{P}_{45} \mathrm{~K}_{45}, \mathrm{~N}_{60}+\mathrm{N}_{30}, \mathrm{P}_{90} \mathrm{~K}_{90}$ коливався в межах 4,26-5,35 мг/кг. У цілому, застосування інших норм органічних і мінеральних добрив призводило до незначного збільшення вмісту міді в соломі озимої пшениці. За мінімального захисту на 12-ти варіантах удобрення вміст міді в соломі коливався в межах 3,18-4,51 мг/кг.

Висновки. Результати екотоксикологічних досліджень дозволили виявити, що мінеральна система удобрення та інтенсивний захист рослин можуть бути причиною нагромадження потенційно небезпечних шкідливих речовин у верхніх горизонтах грунту, а також сприяти їх міграції вниз за грунтовим профілем і створювати потенційну загрозу забруднення грунтових вод. Органічна система удобрення, навпаки, сприяла зниженню активності цих процесів. 


\section{СІЛЬСЬКЕ ГОСПОДАРСТВО. РОСЛИННИЦТВО}

Було встановлено, що під впливом мінеральних добрив $\left(\mathrm{P}_{135} \mathrm{~K}_{135}+\mathrm{N}_{80}+\mathrm{N}_{55}, \mathrm{P}_{90} \mathrm{~K}_{90} \mathrm{~N}_{60}+\mathrm{N}_{30}\right.$, $\mathrm{N}_{45} \mathrm{P}_{45} \mathrm{~K}_{45}$ ) на фоні інтенсивного захисту відбувалося більш активне накопичення потенційно небезпечних речовин вегетативними (стебло, листя) органами пшениці. Застосування побічної продукції призводило до зниження активності цих процесів. Системи удобрення та, особливо, захисту рослин мали істотний вплив на перерозподіл шкідливих речовин між вегетативними та

\section{БІБЛІОГРАФІЯ}

1. Жигарева Т. Л. Влияние природных мелиорантов и тяжелых металлов на урожайность зерновых культур и микрофлору дерновоподзолистой почвы / Т. Л. Жигарева, Р. М. Алексахин, Д. Г. Свириденко // Агрохимия. - 2005. № $11 .-$ С. 60-65.

2. Кринвіч Н. Я. Вміст важких металів у грунті під озимою пшеницею та іiі продуктивність залежно від систем удобрення та способів основного обробітку / Н. Я. Кривіч, Ю. А. Білявський, Я. П. Мандзик // Вісник ДАУ. - 2004. - № 1. - C. 61-68.

3. Методические указания по определению тяжелых металлов в почвах сельскохозяйствен-

\section{ANNOTATION}

Togachyns'ka O. V., Parashchenko I. V. The translocation of the transition of copper from a dark gray podzolized soil to winter wheat plants.

The research was carried out on the basis of the Institute of Agroecology of the UAAS and the NSC «Institute of Agriculture of UAAS». Winter wheat variety - Lada Odes'ka. The soil of the experimental field is dark gray podzolized.

The scheme of the experiment involved the study of fertilizer variants against the background of the minimal and intensive system of plant protection: control (without fertilizers), $\mathrm{N}_{60} \mathrm{~N}_{30}, \mathrm{P}_{135} \mathrm{~K}_{135}+\mathrm{N}_{80}+$ $\mathrm{N}_{55}$, by-products, $\mathrm{P}_{90} \mathrm{~K}_{90}+\mathrm{N}_{60}+\mathrm{N}_{30}$.

The results of ecological examination of technologies of winter wheat growing in the Northern Forest-Steppe for the influence on the processes of copper migration in the genetic horizons of dark gray podzolized soil and its accumulation in vegetative and generative organs of plants are highlighted. The results of ecotoxicological studies have revealed that the mineral fertilizer system and intensive plant protection can cause the accumulation of potentially hazardous substances in the upper horizons of the soil. As well as promote their migration down the генеративними органами пшениці. Кількість їх в зерні озимої пшениці за інтенсивного захисту рослин значно зростала.

Наша наукова роботи в подальшому буде спрямована на вивчення впливу транслокації переходу нікелю, цинку з грунту у вегетативні і генеративні органи озимої пшениці та проведення екологічної оцінки технологій вирощування озимої пшениці за токсикологічними показниками.

ных угодий и продукции растениеводства / ЦИНАО. - М. : ЦИНАО, 1992. - 61 с.

4. Методичні рекомендації "Екологічна експертиза технологій вирощування сільськогосподарських культур" / [За ред. д. с.-г. наук Н.А. Макаренко, к. с.-г. н. В.В. Макаренка/ K., 2008. -84 c.

5. Популан M. I. Родючість грунту як природно - антропогенна його властивість, ії види та параметрична оцінка / М. I. Популан, В. А. Величко, В. Б. Соловей // Вісник аграрної науки. 2009. - № 2. - С. 17-24.

soil profile and create a potential threat to groundwater contamination.

It was established that under the influence of mineral fertilizers $\left(\mathrm{P}_{135} \mathrm{~K}_{135}+\mathrm{N}_{80}+\mathrm{N}_{55}, \mathrm{P}_{90} \mathrm{~K}_{90} \mathrm{~N}_{60}+\right.$ $\mathrm{N}_{30}, \mathrm{~N}_{45} \mathrm{P}_{45} \mathrm{~K}_{45}$ ) intensive protection was carried out more active accumulation of potentially dangerous substances by vegetative (stem, leaves) by the organs of wheat. The use of by-products led to a decrease in the activity of these processes. Fertilizer systems, and especially plant protection, have had a significant impact on the redistribution of harmful substances between vegetative and generative organs of wheat. The amount of copper in winter wheat grains with intensive plant protection increased significantly.

Prospects for scientific work in the future will be aimed at studying the influence of the transition of the transition of nickel, zinc from the soil into vegetative and generative organs of winter wheat and conducting an environmental assessment of technologies for growing winter wheat according to toxicological indicators.

Key words: winter wheat, ecological assessment, dark-gray podzolized soil, sanitary-hygienic indices, copper, grain. 